\title{
RECOVERY OF SIMPLE HAND FUNCTION IN TETRAPLEGIA PATIENTS FOLLOWING TRANSFER OF THE MUSCULO-CUTANEOUS NERVE INTO THE MEDIAN NERVE
}

\author{
By JERZY KIWERSKI \\ Institute of Rehabilitation, Warsaw School of Medicine, Konstancin, Nr. Warsaw, Poland.
}

\begin{abstract}
Transfer of the musculo-cutaneous nerve into the median nerve makes it possible in most cases to reproduce simple function in the tetraplegic hand. The results of this procedure in 20 patients with complete traumatic cervical spine injury are discussed.
\end{abstract}

Key words: Tetraplegia; Spinal cord injuries; Function of the paralysed hand; Transfer of the musculo-cutaneous nerve onto the median nerve.

\section{Introduction}

Following injuries of the cervical spinal cord at the common level with C6 neurological level sparing, abduction of the shoulder and elbow flexion remain active. With the simultaneous complete paralysis of the distal part of the limb, the function of these muscles is however of no practical value. Moreover the unaffected function of these active muscles may produce contractures. Flexors of the elbow are controlled by the musculo-cutaneous nerve formed mainly by the fibres from $\mathrm{C}_{5}$ and C6, the motor cells of which are usually located above the level of the spinal lesion.

This observation was utilised for the first time by Benassy and Robart, who in 1966 reported a case of transferring the musculo-cutaneous nerve into the median nerve in the paralysed limb. The proximal stubb of the divided musculocutaneous nerve is anastomosed with the distal end of the median nerve. This report encouraged us to perform a similar operation in 20 cases of tetraplegia.

\section{Clinical material}

Clinical details are presented in the Table I. Surgery was performed in 20 patients, all but one being male. They were mostly young people 17-25 years of age, the oldest being 52 years old. (Average age 25.2 years). The commonest cause of injury (in I4) was a dive into shallow water. Surgery was performed from I to Io months after trauma and the follow-up period was from I 8 months to 8 years (average 5 years). Because of the long period of nerve regeneration, tissue reinnervation and progressing functional improvement, we are of the opinion that evaluation before a lapse of 18 months is unsuitable.

\section{Surgical technique}

Under general anaesthetic a Io $\mathrm{cm}$ long skin incision was made on the medial aspect of the arm from the axilla down between the flexors and extensors of the 
TABLE I

\begin{tabular}{|c|c|c|c|c|c|c|c|c|c|}
\hline No. & Initials & Sex & Age & Trauma cause & $\begin{array}{l}\text { Level of } \\
\text { SC injury }\end{array}$ & $\begin{array}{l}\text { Time: trauma } \\
\text { - surgery }\end{array}$ & Fusion type & $\begin{array}{c}\text { Observation } \\
\text { time }\end{array}$ & Results \\
\hline I & P. J. & $\mathrm{m}$ & I8 & diving & C6 & 3 months & $\begin{array}{l}\text { m-cut. + cut. } \\
\text { + med. }\end{array}$ & 9 years & good \\
\hline 2 & K. Z. & $\mathrm{m}$ & 42 & road accident & $\mathrm{C}_{7}$ & 5 months & $\begin{array}{l}\text { m-cut. + cut. } \\
\text { + med. }\end{array}$ & 3 years & satisfactory \\
\hline 3 & H. J. & $\mathrm{m}$ & 52 & fall from a cart & $\mathrm{C}_{7}$ & 7 months & $\begin{array}{l}\text { m-cut. + cut. } \\
\text { + med. }\end{array}$ & 3 years & bad \\
\hline 4 & J. M. & $\mathrm{m}$ & 20 & diving & C6 & 4 months & $\begin{array}{l}\text { m-cutaneous } \\
\text { + med. }\end{array}$ & 7 years & good \\
\hline 5 & B. W. & $\mathrm{m}$ & I7 & diving & C6 & 6 months & $\begin{array}{l}\text { m-cutaneous } \\
\text { + med. }\end{array}$ & 5 years & satisfactory \\
\hline 6 & K. R. & $\mathrm{m}$ & 24 & diving & $\mathrm{C}_{7}$ & 3 months & $\begin{array}{l}\text { m-cut. + cut. } \\
\text { + med. }\end{array}$ & 6 years & good \\
\hline 7 & M. Z. & $\mathrm{m}$ & 34 & fall from a cart & C6 & 5 months & $\begin{array}{l}\text { m-cut. + cut. } \\
\quad+\text { med. }\end{array}$ & 7 years & satisfactory \\
\hline 8 & M. W. & $\mathrm{m}$ & I8 & diving & C6 & I month & $\begin{array}{l}\text { m-cut. + cut. } \\
\quad+\text { med. }\end{array}$ & 6 years & good \\
\hline 9 & F. L. & $\mathrm{m}$ & 23 & diving & $\mathrm{C}_{7}$ & 6 months & $\begin{array}{l}\text { m-cutaneous } \\
\text { + med. }\end{array}$ & 6 years & satisfactory \\
\hline IO & M. J. & $\mathrm{m}$ & 33 & road acciednt & $\mathrm{C6}$ & IO months & $\begin{array}{l}\text { m-cut. + cut. } \\
\text { + med. }\end{array}$ & 5 years & bad \\
\hline I2 & S. B. & w & 18 & raad accident & $\mathrm{Co}$ & 3 months & $\begin{array}{l}\text { m-cutaneous } \\
\text { + med. }\end{array}$ & 5 years & good \\
\hline & W. 1. & $1 \pi$ & 24 & & C7 & 0 111011Lis & $\begin{array}{l}\text { m-cut. + cut. } \\
\text { + med. }\end{array}$ & 5 years & Dau \\
\hline 13 & S. $Z$. & $\mathrm{m}$ & 19 & diving & C6 & 2 months & $\begin{array}{l}\text { m-cut. + cut. } \\
\text { + med. }\end{array}$ & 6 years & good \\
\hline I4 & R. M. & $\mathrm{m}$ & 23 & diving & C6 & 7 months & $\begin{array}{l}\text { m-cutaneous } \\
\text { + med. }\end{array}$ & 7 years & bad \\
\hline I5 & M. W. & $\mathrm{m}$ & $2 \mathrm{I}$ & diving & C6 & 3 months & $\begin{array}{l}\text { m-cut. + cut. } \\
\text { + med. }\end{array}$ & 4 years & good \\
\hline I6 & K. M. & $\mathrm{m}$ & I9 & diving & C6 & 6 months & $\begin{array}{l}\text { m-cut. + cut. } \\
\quad+\text { med. }\end{array}$ & 5 years & satisfactory \\
\hline I7 & M. A. & $\mathrm{m}$ & 24 & diving & $\mathrm{C}_{7}$ & 5 months & $\begin{array}{l}\text { m-cut. + cut. } \\
\text { + med. }\end{array}$ & 4 years & satisfactory \\
\hline I8 & C. J. & $\mathrm{m}$ & 35 & road accident & C6 & 7 months & $\begin{array}{l}\text { m-cut. + cut. } \\
\text { + med. }\end{array}$ & 4 years & bad \\
\hline 19 & R. P. & $\mathrm{m}$ & I8 & diving & C6 & 2 months & $\begin{array}{l}\text { m-cut. + cut. } \\
\quad+\text { med. }\end{array}$ & 2 years & good \\
\hline 20 & J.A. & $\mathrm{m}$ & $2 I$ & diving & C6 & 3 months & $\begin{array}{l}\text { m-cut. + cut. } \\
\quad+\text { med. }\end{array}$ & I. 5 years & good \\
\hline
\end{tabular}


elbow. The median, musculo-cutaneous and medial cutaneous of arm nerves are identified. The median nerve is divided sharply at the upper end of the wound and the musculo-cutaneous nerve divided $2 \mathrm{~cm}$ lower, but always above its branch to the brachialis. The division is usually between the branches going off to the short and long heads of the biceps. When there is a marked difference of diameter of both nerves, the medial cutaneous nerve of the arm is divided at the same level (I 5 cases). The division of the nerves at different levels allows their ends to be joined without tension thus enabling their exact cooptation and repair. The proximal ends of the musculo-cutaneous and medial cutaneous nerves are sutured to the distal end of the median nerve using autogenous blood serum (Tarlov, 1942; Haftek, 1964; Kiwerski, 1972). The wound is closed in layers, a sterile dressing applied and the limb immobilised in a plaster slab. No complications were observed in any of the cases. The plaster slab was removed after 2 weeks, and rehabilitation started the following week restores passive mobility. Management in the postoperative period was the same as after repair of peripheral nerves (Kiwerski, I97I ; Haftek, I972; Weiss, I972).

\section{Results}

Restoration of grasp to the hand after operation is not wholly satisfactory. However, taking into consideration the complete lack of active finger flexion before operation, the recovery of grasp is assessed very positively by the patients. Such mobility is assessed as a good result, if also accompanied by marked improvement of tactile gnosis and discrimination of touch, pain and temperature. A weaker but useful grip, with poorer discrimination of touch, pain and temperature qualifies as a satisfactory result. Lack of useful grip is considered a bad result.

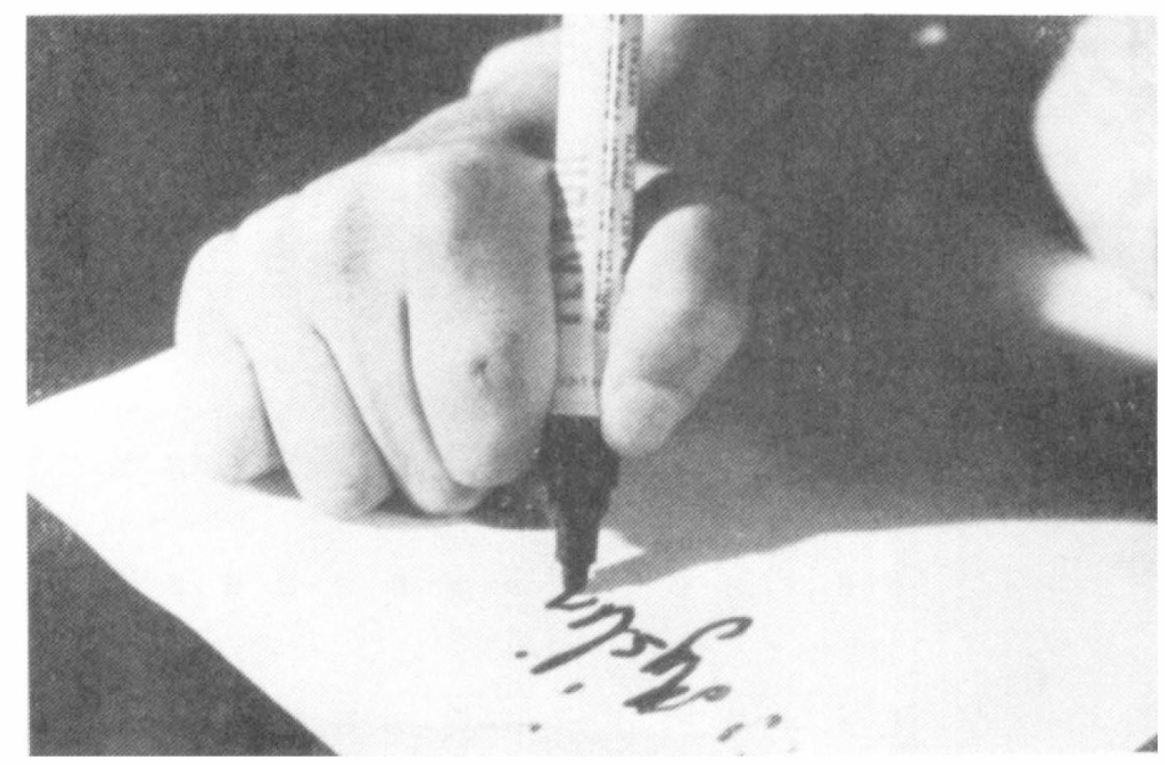

FIG. I

The patient M.W.-after successful transposition of the musculo-cutaneous nerve on the median nerve-undertakes the test of writing. 
Of the 20 patients, good results were achieved in nine, satisfactory results in six and poor results in five.

For a patient lacking ability of the slightest movement of the hand, the recovery of even minimal motion is a cause for happiness and may make possible the writing of a letter (Fig. I), eating (Fig. 2) or smoking a cigarette (Fig. 3).

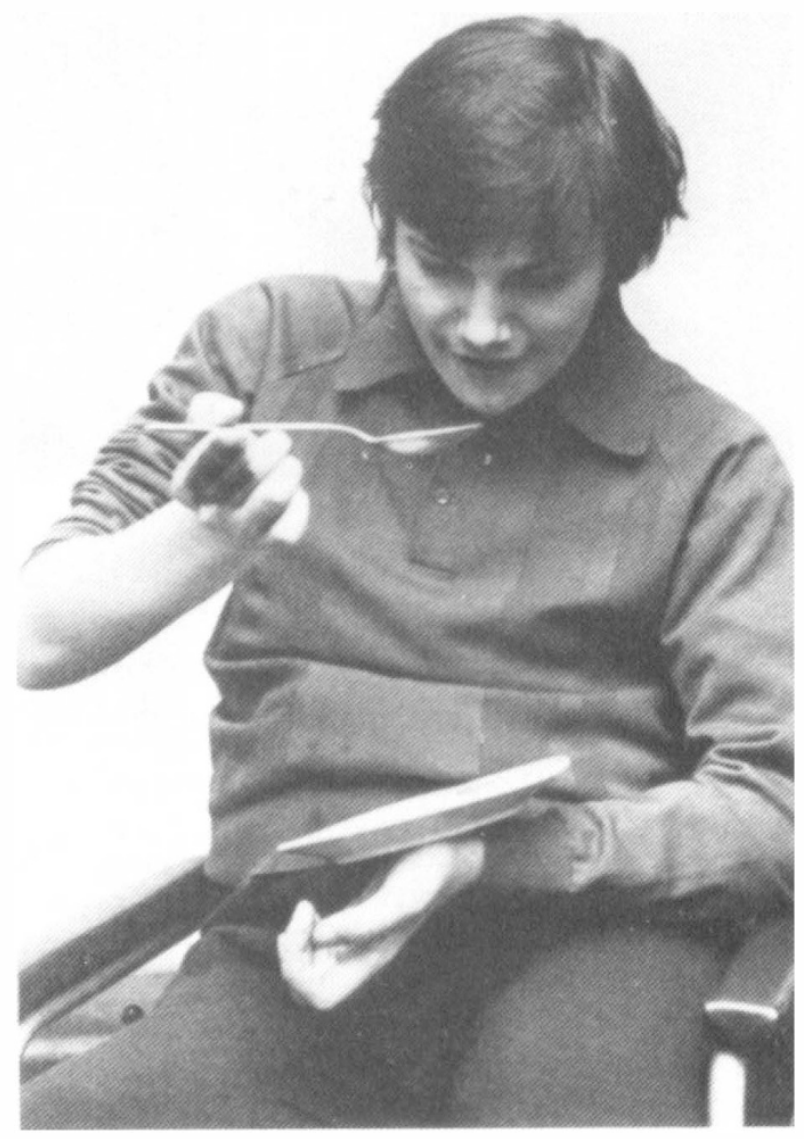

FIG. 2

The manner of holding the spoon by the patient J. M. during eating.

\section{Discussion}

The ability to carry out simple everyday activities of gripping, which may be gained after the operation eliminates the feeling of complete helplessness and dependence. The operation is thus fully justifiable in selected cases of complete paralysis of the cervical spinal cord at the level C6 and C7. Any risk of operation is minimal; it is practically bloodless and may be performed under local anaesthesia. Poor recovery is rare and does not jeopardise the general condition of the hand. The partial denervation of the flexors of the elbow joint does not weaken the function of the limb. Definite improvement of sensory and trophic functions in the median nerve distribution was observed in all patients. 


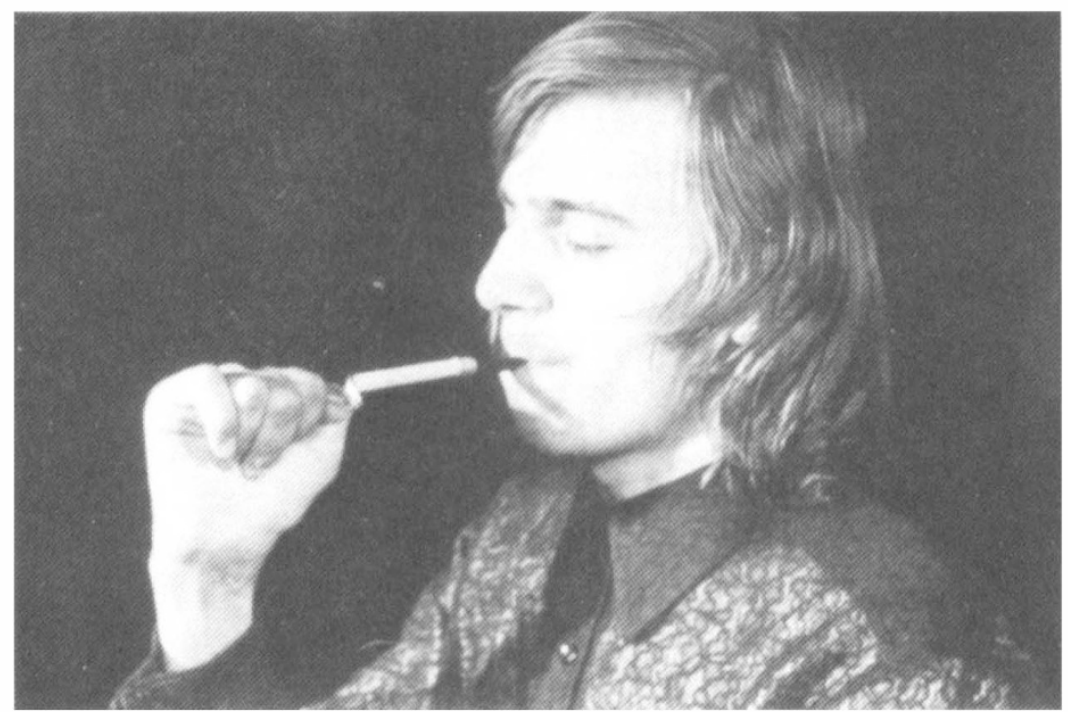

FIG. 3

Patient P. J. lighting a cigarette with a match.

The best results are obtained in young people. In many cases, when taking into consideration mechanism of the injury, the degree of displacement of vertebrae and persisting symptoms of complete interruption of the long spinal paths, where we consider soon after injury that the cord damage is complete and permanent. We believe that early operation is justified.

Following successful anastomosis of nerves the function of the hand is often impaired still by paralysis of finger extensors. Then, the use of the extension splint supporting the fingers (Weiss, I972) is helpful.

\section{Conclusions}

I. Transfer of the musculo-cutaneous nerve into the median nerve creates favourable conditions for the regeneration of the median nerve and the reinnervation of tissues it supplies.

2. In most cases the operation restores simple grip functions thus decreasing the patient's helplessness and dependence.

3. The operation is especially indicated in complete lesions of the spinal cord at the level of $\mathrm{C}_{6}$ and $\mathrm{C}_{7}$ in young people and should be performed soon after the injury; this improves the change of restoration of hand function for everyday activities.

\section{SUMMARY}

The encouraging report of anastomosis of the musculocutaneous nerve to the median nerve, described by Bennassy and Robart, induced us to perform similar surgery in 20 patients with traumatic tetraplegia. In I 5 patients this has restored simple grasping function of the hand, increasing the patient's independence. It is particularly indicated in cases of complete injury of the spinal cord at $\mathrm{C}^{6}-\mathrm{C}_{7}$ level 
in young people, and should be performed in the first months after trauma, thus improving the recovery.

\section{RÉSUMÉ}

Le rapport encourageant sur l'anastomose du nerf musculo-cutané sur le nerf médian, écrit par Bennassy et Robart, nous a induit à pratiquer une opération similaire chez 20 tétraplégiques post-traumatiques. Chez I5 blessés ceci a restauré une fonction de préhension accroissant l'indépendance de la personne. Cette opération est particuilèrement indiquée dans le cas de lésions complètes de niveau $\mathrm{C}_{6}-\mathrm{C}_{7}$ chez des personnes jeunes et devrait être effectuée dans les premiers mois après le traumatisme de façon à augmenter les chances de réussite.

\section{ZUSAMMENFASSUNG}

Der ermutigende Bericht von BENNASSI und ROBART über die Tranplantation des N. musculo-cutaneus auf den N. medianus hat uns dazu angeregt, diese Operation bei 20 Patienten mit einer traumatischen Tetraplegie durchzuführen. Bei I5 Patienten kam es dadurch zur Wiederherstellung des Grobgriffes der Hand, also zu einer Zunahme der Unabhängigkeit. Eine spezielle Indikation besteht bei jungen Menschen mit einer Verletzung des Rückenmarkes in Höhe von C 6/7. Die Operation sollte innerhalb des ersten Monats nach der Verletzung durchgeführt werden, um dadurch die Heilungsaussichten zu verbessern.

\section{REFERENCES}

Benassy, J. \& Robart, J. (1966). Un cas de transposition musculo-cutane sur le nerf median. Annales de Chirurgie Plastique, II, I87-I89.

Haftek, J. (I965). Gluing of peripheral nerve by means of own-derived plasma. Polski Przegl. Chirurg., 37, 947-952.

HAfTEK, J. (1972). Principles of medical improving patients with peripheral nerve injury. In: Hausmanowa-Petrusewicz I. and co-workers: Diseases of peripheral nerves. PZWLWarszawa, pp. 379-384 (In Polish).

Kiwerski, J. (I97I). Rehabilitation methods after nerve injuries. Polski Tyg. Lakarski, 19, 726-729.

KIWERSKI, H. (1972). Results of the 'end to end' nerve sutures. Chir. Narz. Ruchu $i$ Ortop. Pol., 37, 257-260.

Tarlov, J. M. \& Benjamin, B. (1942). Autologus plasma clot suture of nerves. Science, 95, $258-263$.

WEISS, M. (I972). Rehabilitation of patients with peripheral nerves injury after operational reconstruction. In: Hausmanowa-Petrusewicz, I.: Diseases of peripheral nerves. PZWL-Warszawa, 393-405 (In Polish). 